\title{
Rapid Assembly of Yeast Expression Cassettes for Phenylpropanoid Biosynthesis in Saccharomyces cerevisiae
}

(Pemasangan Pantas Gen Kaset Yis untuk Penghasilan Fenilpropanoid dalam Saccharomyces cerevisiae)

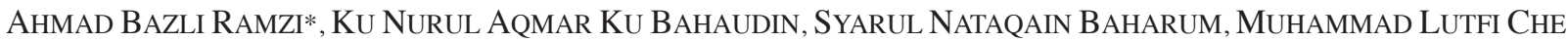 \\ ME, HOE-HAN GOH, MAIZOM HASSAN \& NORMAH MOHD NOOR
}

\begin{abstract}
Microbial production of natural products using metabolic engineering and synthetic biology approaches often involves the assembly of multiple gene fragments including regulatory elements, especially when using eukaryotes as hosts. Traditional cloning strategy using restriction enzyme digestion and ligation are laborious and inflexible owing to the high number of sequential cloning steps, limited cutting sites and generation of undesired 'scar'sequences. In this study, a homology-based isothermal DNA assembly method was carried out for one-step simultaneous assembly of multiple DNA fragments to engineer plant phenylpropanoid biosynthesis in Saccharomyces cerevisiae. Rapid construction of yeast plasmid harboring dual gene expression cassettes was achieved via isothermal assembly of four DNA fragments designed with 20 bp overlapping sequences. The rate-limiting enzyme of phenylpropanoid pathway, cinnamate 4-hydroxylase encoded by $\mathrm{C} 4 \mathrm{H}$ gene from Polygonum minus was cloned in tandem with yeast promoter and terminator elements of $\mathrm{S}$. cerevisiae for efficient construction of phenylpropanoid biosynthetic pathway in recombinant yeast. The assembled pAGCAT (C4H-ADH1t-TEF1p) shuttle plasmid and transformation of $\mathrm{S}$. cerevisiae with the plant $\mathrm{C} 4 \mathrm{H}$ gene were confirmed via PCR analysis. Based on these findings, the yeast shuttle plasmid harboring P. minus phenylpropanoid biosynthesis gene was efficiently constructed to be the starting platform for the production of plant natural products in geneticallyengineered $\mathrm{S}$. cerevisiae.
\end{abstract}

Keywords: Phenylpropanoid biosynthesis; Polygonum minus; rapid DNA assembly; Saccharomyces cerevisiae; synthetic biology

\section{ABSTRAK}

Penghasilan produk semula jadi oleh mikrob melalui kaedah kejuruteraan metabolik dan biologi sintetik sering melibatkan pemasangan serpihan gen berganda termasuk elemen gen pengawalselia yang penting untuk sistem eukariot. Pengklonan gen secara tradisi menggunakan enzim pemotongan dan penyambungan DNA adalah sukar dan tidak fleksibel kerana bergantung kepada langkah pengklonan berjujukan yang sangat banyak, ketidaksesuaian tapak pemotongan dan penghasilan jujukan 'parut'yang tidak dikehendaki. Kajian ini melaporkan pemasangan berbilang fragmen DNA berganda secara serentak dan dalam satu langkah melalui kaedah pemasangan DNA isoterma untuk penghasilan fenilpropanoid dalam yis Saccharomyces cerevisiae. Pembinaan plasmid konstruk yis telah berjaya dilakukan dengan pantas melalui kaedah pemasangan isoterma empat fragmen DNA yang telah direka untuk mengandungi jujukan bertindih sebanyak 20 pasangan bes. Enzim sinamat 4-hidrolase $(\mathrm{C} 4 \mathrm{H})$ daripada Polygonum minus yang merupakan enzim pengehad kadar fenilpropanoid, telah dipasang bersama elemen penggalak dan penamat yis untuk pembinaan laluan fenilpropanoid dalam S. cerevisiae rekombinan secara cekap dan pantas. Hasil pemasangan plasmid lengkap pAG-CAT (C4H-ADHItTEF 1p) dan transformasi gen $\mathrm{C} 4 \mathrm{H}$ dalam $\mathrm{S}$. cerevisiae telah disahkan melalui analisis tindak balas rantai polimerase (PCR). Berdasarkan hasil kajian ini, plasmid ulang-alik yis yang mengandungi gen biosintetik fenilpropanoid daripada P. minus telah berjaya dibina dengan cekap dan akan dijadikan sebagai landasan pemula untuk penghasilan produk semula jadi menggunakan S. cerevisiae yang terubah suai secara genetik.

Kata kunci: Biologi sintetik; biosintesis fenilpropanoid; pemasangan DNA pantas; Polygonum minus; Saccharomyces cerevisiae

\section{INTRODUCTION}

Advances in metabolic engineering and synthetic biology fields have rapidly enabled the production of pharmaceuticals, natural products and biofuels using microorganisms as cell factories (Smanski et al. 2016; Stephanopoulos 2012). Escherichia coli and
Saccharomyces cerevisiae are two of the most established microbial systems for the production of various products (Liu et al. 2013). Production of natural products such as terpenoids, flavonoids and alkaloids often requires the construction of multiple gene fragments for the expression of corresponding biosynthetic pathways 
(Galanie et al. 2015; Trantas et al. 2009). Molecular cloning of genes from various genetic sources have been well established using the restriction enzyme digestion and ligation methods of the gene of interests in bacterial plasmid vectors (Cohen et al. 1973; Sambrook et al. 1989). Although effective, this cloning method is unsuitable for high throughput and rapid DNA assembly of multiple fragments due to rigid requirements of restriction enzyme sites and lack of versatility in vector design (Festa et al. 2013; Hartley et al. 2000).

The restriction enzyme-based techniques are limiting multiple gene cloning and seamless eukaryotic plasmid construction due to the requirements of promoter and terminator regulatory regions for driving and regulating the expression of the individual coding sequences (Blount et al. 2012; Hawkins \& Smolke 2008). A standardized method that enables rapid assembly of multiple gene fragments for metabolic engineering and synthetic biology applications would be particularly useful in rapid eukaryotic strain development especially for the biosynthesis of plant metabolites that often requires the construction of complex biosynthetic pathways.

For this purpose, this study was designed to demonstrate the application of the homology-based DNA assembly technique for rapid and efficient construction of yeast plasmid to express plant phenylpropanoid biosynthesis gene in recombinant $S$. cerevisiae. Here we report the assembly of cinnamate 4-hydroxylase $(\mathrm{C} 4 \mathrm{H})$ gene from medicinal plant Polygonum minus with yeast transcriptional regulatory elements using isothermal DNA assembly. A specially-designed strategy was devised for rapid construction of double expression cassettes that will enable co-expression of genes for the plant phenylpropanoid biosynthesis pathway in recombinant yeast.

\section{MATERIALS AND METHODS}

\section{STRAINS AND CULTIVATION CONDITIONS}

For plasmid propagation and molecular cloning, E. coli TOP10 strain was used. Luria Bertani (LB) medium (10 $\mathrm{g} / \mathrm{L}$ tryptone, $5 \mathrm{~g} / \mathrm{L}$ yeast extract and $10 \mathrm{~g} / \mathrm{L}$ sodium chloride) with $100 \mu \mathrm{g} / \mathrm{mL}$ ampicillin or $50 \mu \mathrm{g} / \mathrm{mL}$ kanamycin was used for plasmid preparation and maintenance. S. cerevisiae CEN.PK 2-1C was used for yeast transformation and plasmid propagation. YPD medium (10 g/L yeast extract, $20 \mathrm{~g} / \mathrm{L}$ peptone, $20 \mathrm{~g} / \mathrm{L}$ dextrose) was used for yeast cultivation and synthetic dropout (SD) medium lacking histidine (SD-His') was used for yeast transformant selection (Sherman 1991). Bacterial and yeast cells were grown at $37^{\circ} \mathrm{C}$ and $30^{\circ} \mathrm{C}$, respectively, with shaking at $200 \mathrm{rpm}$ where appropriate. $P$. minus was grown in an experimental plot at Universiti Kebangsaan Malaysia, Bangi. Fresh leaves of P. minus were sampled for the RNA isolation and cDNA synthesis (Loke et al. 2017).

\section{NUCLEIC ACID ISOLATION, AMPLIFICATION AND SEQUENCING}

Isolation of total RNA and cDNA synthesis from $P$. minus leaf was respectively carried out using Spectrum ${ }^{\mathrm{TM}}$ Plant Total RNA Kit (Sigma Aldrich, USA) and Maxima First Strand cDNA Synthesis Kit (Thermo Scientific, USA) according to the manufacturer's instructions. Plasmid isolation in bacterial and yeast cells was performed using Zyppy $^{\mathrm{TM}}$ Plasmid Miniprep Kit and Zymoprep ${ }^{\mathrm{TM}}$ Yeast Plasmid Miniprep II (Zymo Research, USA), respectively, by following the kit instructions. PCR products were purified using NucleoSpin ${ }^{\circledR}$ Gel and PCR Clean-up Kit (Macherey-Nagel, USA). DNA primers synthesis and sequencing analysis were performed by First BASE Laboratories (First BASE Laboratories, Malaysia). High fidelity DNA polymerases, Q5 DNA polymerase (New England Biolabs, USA) and KOD FX Neo (Toyobo, Japan) were used for high fidelity amplification of DNA fragments. DpnI restriction enzyme (New England Biolabs, USA) was used to treat vector fragment to reduce vector background in E. coli transformants.

\section{CONSTRUCTION OF YEAST PLASMID}

Yeast plasmid pAG423GPD-ccdB-Cerulean (Addgene, Cambridge, USA, plasmid \# 14390) was used as the expression vector. In this study, four DNA fragments including pAG vector, $\mathrm{C} 4 \mathrm{H}$ gene, $\mathrm{ADH} 1$ terminator, and TEF1 promoter fragments were assembled using isothermal reaction of NEBuilder ${ }^{\circledR}$ HiFi DNA Assembly (New England Biolabs, USA) to yield pAG-CAT (C4H-ADH1tTEF1p) vector. The DNA fragments were joined together via 20 bp-overlapping sequences in respective individual primer sets designed using NEBuilder $\AA^{\circledR}$ Assembly Tool (nebuilder.neb.com). The Vector fragment was amplified from CYC1 terminator to GPD promoter sequences in the original pAG423GPD-ccdB-Cerulean plasmid vector using Polymerase Chain Reaction (PCR) amplification. Fragments of TEF1 promoter and ADH1 terminator were PCR amplified using pCEV-G3-Km (Addgene, Cambridge, USA, plasmid \# 46817) as the DNA template. C4H Fragment was obtained by amplifying $P$. minus cDNA using $P$. minus transcriptome dataset (Loke et al. 2017, 2016). Products obtained from PCR reactions were purified and assembled in 1:5 vector: insert ratio by incubating with NEBuilder® $\mathrm{HiFi}$ DNA Assembly Master Mix for $1 \mathrm{~h}$. The assembled fragments were subsequently transformed into E. coli Top 10 competent cells using heat shock method (Sambrook et al. 1989). Colony PCR of E. coli transformants was performed using KOD FX Neo DNA polymerase (Toyobo, Japan) to confirm the assembly of the 4 fragments in E. coli. Positive transformants exhibiting corresponding PCR products were subcultured for plasmid isolation and verification of correct nucleotide sequences via DNA sequencing.

\section{PLASMID TRANSFORMATION IN S. CEREVISIAE}

The recombined pAG-CAT shuttle plasmid containing $C 4 H$ gene was transformed into $S$. cerevisiae competent 
cells using Frozen-EZ Yeast Transformation II Kit ${ }^{\mathrm{TM}}$ (Zymo Research, USA) following the kit instruction manual. Briefly, $5 \mu \mathrm{L}$ of purified DNA sample was mixed with the frozen yeast competent cells and incubated at $30^{\circ} \mathrm{C}$ for $1 \mathrm{~h}$ with intermittent shaking in every $15 \mathrm{~min}$. The mixture was resuspended with 2x YPD medium and incubated at $30^{\circ} \mathrm{C}$ overnight or for at least $1 \mathrm{~h}$ prior to spreading onto selective SD-His agar plate. Transformed yeast were incubated for 2-3 days at $30^{\circ} \mathrm{C}$ and colony PCR was performed on selected yeast colonies to confirm the insertion of $\mathrm{C} 4 \mathrm{H}$ gene in the yeast cells using KOD FX Neo DNA polymerase protocol (Toyobo, Japan). The $C 4 H$ gene sequence from the yeast colony PCR was verified via DNA sequencing. All plasmids and strains employed in this study are listed in Table 1.

\section{RESULTS AND DISCUSSION}

\section{RAPID CONSTRUCTION OF YEAST VECTOR FOR EXPRESSING PLANT BIOSYNTHETIC GENES}

In this study, we aimed to construct yeast vector for the expression of phenylpropanoid biosynthetic gene via one-step and seamless DNA assembly method. Insert DNA fragments were designed in tandem with yeast regulatory elements for the creation of double expression cassettes under the control of strong constitutive GPD and TEF1 promoters. To express phenylpropanoid biosynthetic pathway in yeast, the rate-limiting enzyme cinnamate 4-hydroxylase encoded by $\mathrm{C} 4 \mathrm{H}$ gene was cloned in the first expression cassette. As illustrated in Figure 1, the cloning of $\mathrm{C} 4 \mathrm{H}$ gene was designed to be located in between the original GPD promoter and newly added ADH1 terminator in the pAG vector. Another promoter, TEF1p was also cloned upstream to the original $\mathrm{CYCl}$ terminator in the pAG423GPD vector (Alberti et al. 2007).
Consequently, this arrangement enables the construction of the second expression cassette by additional cloning of desired coding sequences (CDS) in between the TEF1 promoter and CYC1 terminator. By transforming this pAG-CAT vector in $S$. cerevisiae, the $C 4 H$ gene will be constitutively expressed. The expression of cytochrome $\mathrm{P} 450$-type $\mathrm{C} 4 \mathrm{H}$ enzyme will enable the biosynthesis of plant phenolic compound, p-coumaric acid from transcinnamic acid under the control of the GPD promoter and ADH1 terminator.

\section{ONE-STEP ASSEMBLY OF MULTIPLE DNA FRAGMENTS VIA ISOTHERMAL DNA ASSEMBLY}

For rapid yeast plasmid construction, we carried out homology-based DNA assembly of four DNA fragments to yield pAG-CAT yeast vector. The in vitro DNA assembly was performed by the enzymatic reactions of 5' exonuclease, DNA polymerase and DNA ligase that joined the fragments based on 15-25 bp overlapping regions between adjacent fragments. In this study, three insert fragments, namely $\mathrm{C} 4 \mathrm{H}$, ADH1 and TEF1, were designed to contain $20 \mathrm{bp}$ overlapping sequences to adjacent fragments and between the insert fragments and vector. For DNA propagation in recombinant yeast, a shuttle plasmid pAG423GPD containing $2 \mu$ origin of replication and Histidine auxotrophic marker was employed for the isothermal cloning-based recombination.

Figure 2 depicts the overall construction process of pAG-CAT recombined vector using isothermal assembly method. The $\mathrm{C} 4 \mathrm{H}$ fragment with $1.5 \mathrm{~kb}$ size was obtained via PCR amplification of $P$. minus cDNA. The yeast ADH1 terminator and TEF1 promoter fragments respectively with PCR product sizes of 0.3 and $0.4 \mathrm{~kb}$, were amplified using pCEV-G3-Km yeast vector as the DNA template. Assembly of the four DNA fragments (1 vector, 3 insert fragments) was verified using colony PCR and DNA sequencing PCR

TABLE 1. List of microbial strains and plasmids used in this study

\begin{tabular}{|c|c|c|}
\hline Strain or plasmid & Genotype or construct & $\begin{array}{l}\text { Reference } \\
\text { or source }\end{array}$ \\
\hline \multicolumn{3}{|l|}{ Bacterial strains } \\
\hline $\begin{array}{l}\text { Escherichia coli } \\
\text { TOP10 }\end{array}$ & 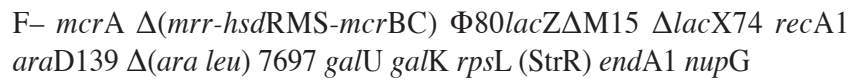 & Invitrogen $^{\mathrm{a}}$ \\
\hline $\begin{array}{l}\text { S.cerevisiae } \\
\text { CEN.PK 2-1C }\end{array}$ & MATa; his3D1; leu2-3_112; ura3-52; trp1-289; MAL2-8c; SUC2 & EUROSCARF $^{b}$ \\
\hline \multicolumn{3}{|l|}{ Plasmids } \\
\hline $\begin{array}{l}\text { pAG423GPD-ccdB- } \\
\text { Cerulean }\end{array}$ & $\begin{array}{l}\text { E. coli-S. cerevisiae shuttle vector, } \\
\mathrm{Cm}^{\mathrm{R}}, \mathrm{Amp}^{\mathrm{R}} \text { His } 3 \text { auxotrophic marker }\end{array}$ & Alberti et al. (2007) \\
\hline pCEV-G3-Km & E. coli-S. cerevisiae shuttle vector, $\mathrm{Amp}^{\mathrm{R}}, \mathrm{G} 418^{\mathrm{R}}$ & Vickers et al. (2013) \\
\hline pAG-CAT & $\begin{array}{l}\text { pAG423GPD-ccdB-Cerulean containing } C 4 H \text { gene, ADH1 terminator, } \\
\text { TEF1 promoter fragments }\end{array}$ & This study \\
\hline
\end{tabular}

Amp, ampicillin; $\mathrm{Cm}$, chloramphenicol; R, resistance

anvitrogen Corporation, Carlsbad, CA, USA

${ }^{\mathrm{b}}$ European Saccharomyces cerevisiae Archive for Functional Analysis (EUROSCARF), Frankfurt, Germany 


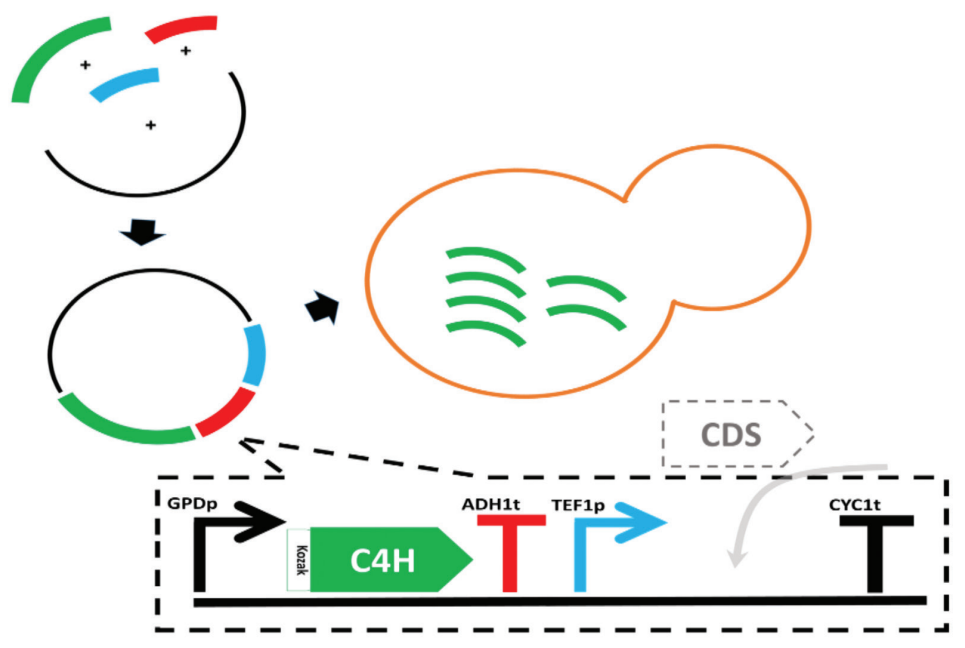

FIGURE 1. A simplified scheme for in vitro DNA assembly and construction of yeast plasmid with double expression cassettes. Three insert fragments ( $C 4 H$ gene, $\mathrm{ADH} 1$ terminator and TEF1 promoter) were assembled with linear yeast plasmid fragment in $E$. coli via isothermal reactions. The $C 4 H$ gene from $P$. minus will be expressed heterologously in recombinant $S$. cerevisiae under the control of GPD promoter in the first expression cassette. Additional coding sequences (CDS) can be cloned in the second expression cassette under the control of TEF1 promoter

products from the $E$. coli transformants. A total PCR product size of $2.3 \mathrm{~kb}$ was obtained when using $\mathrm{C} 4 \mathrm{H}$ forward and TEF1 reverse primers. This demonstrates the successful assembly of the insert and vector fragments in E. coli. The recombinant $\mathrm{pAG}-\mathrm{CAT}$ (C4H-ADH1t-TEF1p) plasmid with the size of $8.9 \mathrm{~kb}$ attained after a single restriction enzyme digestion further confirmed the complete recombination of the three insert fragments with the constructed plasmid vector using our isothermal assembly strategy.

Overall, three DNA fragments were successfully assembled with vector in a single day and overall process requires a total of 3-5 days for DNA preparation and verification of assembled DNA sequences. This method is highly useful for the one-step and simultaneous construction of multiple 4-6 fragments as compared to traditional restriction-ligation cloning methods that involved multiple sequential steps that are time-consuming, laborious and limited by the availability of restriction enzyme sites (Chen 2016; Wang et al. 2012). In particular, co-expression of enzymes using restriction enzyme sites would require individual plasmid construction prior to obtaining the final multigene plasmid construct (Busso
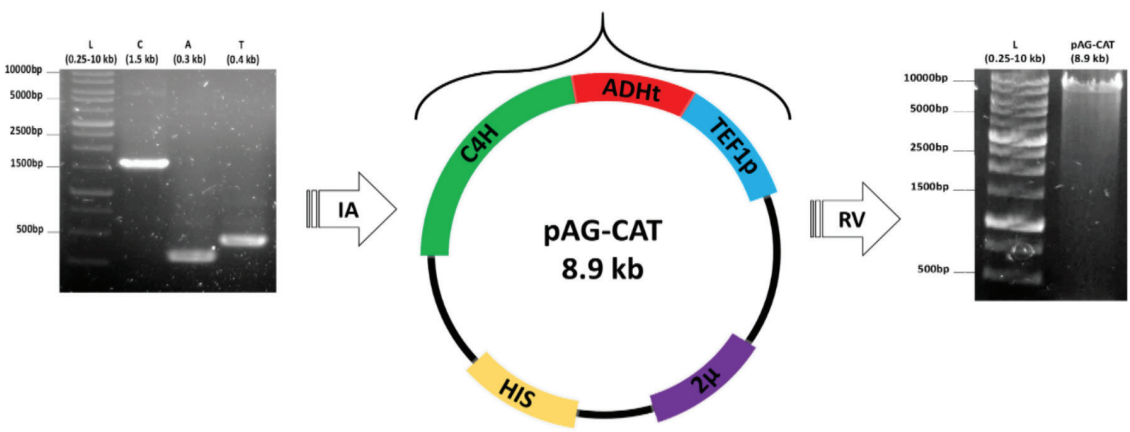

FIGURE 2. Overall construction of pAG-CAT plasmid using isothermal assembly method. Inset figures depicted electrophoresis gel results of respective DNA fragments. Lane C, A, T and CAT represent PCR products of C4H, ADHt, TEF1p and assembled C4H-ADHt-TEF1p fragment, respectively. Lane pAG-CAT indicates the total size of pAG-CAT vector linearized with restriction enzyme digestion. Lane L represents DNA ladder (ExcelBand ${ }^{\mathrm{TM}} 1 \mathrm{~KB}$ (0.25-10 kb) DNA Ladder; SMOBIO,

Taiwan). IA and RV denote for isothermal assembly and recombined vector, respectively 
et al. 2011; Ramzi et al. 2015). The employment of this homology-based assembly approach and other in vitro assembly techniques would further aid in the rapid construction of large constructs, particularly for complex biosynthetic pathways of plant metabolites and antibiotics (Luo et al. 2016).

\section{TRANSFORMATION OF YEAST WITH PHENYLPROPANOID BIOSYNTHETIC GENE FROM P. MINUS}

$S$. cerevisiae has been widely used for the expression of eukaryotic proteins and production of plant-derived metabolites. In this study, we aimed to establish yeast as the cloning and production host of phenylpropanoid and flavonoid biosynthetic pathways based on previous findings of P. minus (Ahmad et al. 2014; Loke et al. 2017) stem and roots. To this end, the cytochrome P450-type $\mathrm{C} 4 \mathrm{H}$ gene from $P$. minus was amplified and assembled in the pAG-CAT shuttle vector for the plasmid transformation in S. cerevisiae CEN.PK 2-1C strain. Yeast transformants were selected for colony PCR analysis using $\mathrm{C} 4 \mathrm{H}$ primer and the presence of $\mathrm{C} 4 \mathrm{H}$ gene was confirmed by the successful amplification and DNA sequencing of the $1.5 \mathrm{~kb}$ PCR products (Figure 3). Similar $1.5 \mathrm{~kb}$ PCR product size was obtained in control of $\mathrm{C} 4 \mathrm{H}$ gene fragment as a template. All yeast colonies that were randomly chosen exhibited the presence of heterologous $\mathrm{C} 4 \mathrm{H}$ gene indicating viable propagation of the $\mathrm{C} 4 \mathrm{H}$-containing $\mathrm{pAG}$-CAT vector in the recombinant $S$. cerevisiae .

$\mathrm{C} 4 \mathrm{H}$ gene is considered the key enzyme in the phenylpropanoid and flavonoid biosynthesis in plant and engineered microbes (Koopman et al. 2012; Trantas et al. 2009). The engineered S.cerevisiae with this rate-limiting enzyme in the phenylpropanoid biosynthesis pathway would therefore serve as a starting platform for further assembly of other flavonoid biosynthetic genes. Compared to $E$. coli, the major advantage of using $S$. cerevisiae as the transformation host is the capacity of yeast to support the expression of membrane-bound cytochrome P450 family that is relatively difficult in E. coli (Leonard \& Koffas 2007; Siddiqui et al. 2012). Furthermore, geneticallyengineered $S$. cerevisiae can be further developed for the heterologous expression and production of plant-derived aromatic compounds owing to its innate capability to support aromatic amino acid metabolism and established genetic tools for efficient overproduction of metabolites that are naturally found in very small amounts (Siddiqui et al. 2012).

Importantly, an additional gene can be cloned in the second expression cassette under the control of the TEF1 promoter and $\mathrm{CYC} 1$ terminator. Upstream gene such as phenylalanine ammonia lyase (PAL) can be expressed for supplying the trans-cinnamate precursor in the recombinant yeast (Yan et al. 2005). Similarly, the catalytic activity of cytochrome $\mathrm{P} 450 \mathrm{C} 4 \mathrm{H}$ can be further improved by co-expressing activating cytochrome $\mathrm{P} 450$ reductase $(C P R)$ gene in the second expression cassette (Koopman et al. 2012). Another key enzyme in the phenylpropanoid biosynthetic pathway, 4-coumarate:CoA ligase (4CL) may also be cloned in the second expression cassette for the biosynthesis of p-Coumaroyl-CoA, an essential precursor for flavonoid and stilbenoid pathway (Jiang et al. 2005; Trantas et al. 2009).

\section{CONCLUSION}

Rapid construction of yeast expression cassettes for phenylpropanoid biosynthesis was successfully demonstrated in the recombinant E. coli and S. cerevisiae. By using this homology-based approach, multiple gene assembly of complex biosynthetic pathway genes can be achieved in shorter time due to the simplicity of the overlapping DNA fragment designs without the constraints form restriction-based cloning. This report will provide the basis to further engineer $S$. cerevisiae for the production of flavonoids and phenolic compounds using metabolic engineering and synthetic biology approaches.

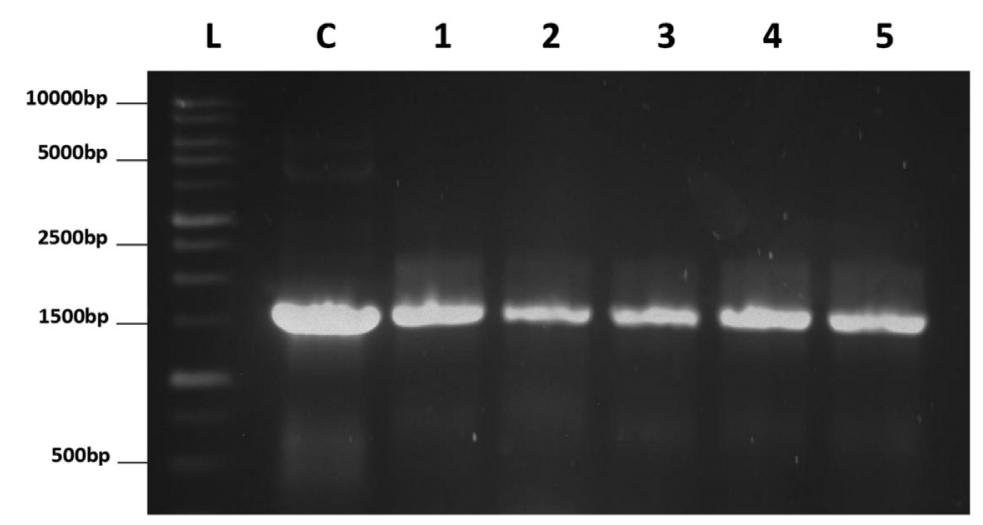

FIGURE 3. Colony PCR results of $C 4 H$ gene in recombinant $S$. cerevisiae cells. Lane 1 to 5 represent specific PCR product of $C 4 H$ gene in yeast cells that were randomly picked. The $C 4 H$ gene sequence from the yeast colony PCR was verified via DNA sequencing. Lane C denotes PCR product of control sample using $\mathrm{C} 4 \mathrm{H}$ fragment from $P$. minus as the template. Lane $\mathrm{L}$ indicates DNA ladder

(ExcelBand $^{\mathrm{TM}} 1 \mathrm{~KB}(0.25-10 \mathrm{~kb})$ DNA Ladder; SMOBIO, Taiwan) 


\section{ACKNOWLEDGEMENTS}

This work is supported by the Academy of Sciences Malaysia (ASM)-Ministry of Science, Technology and Innovation (MOSTI) research grant (RB-2016-001).

\section{REFERENCES}

Ahmad, R., Baharum, S.N., Bunawan, H., Lee, M., Mohd Noor, N., Rohani, E.R., Ilias, N.\& Zin, N.M. 2014 . Volatile profiling of aromatic traditional medicinal plant, Polygonum minus in different tissues and its biological activities. Molecules 19(11): 19220-19242.

Alberti, S., Gitler, A.D. \& Lindquist, S. 2007. A suite of Gateway ${ }^{\circledR}$ cloning vectors for high-throughput genetic analysis in Saccharomyces cerevisiae. Yeast 24(10): 913-919.

Blount, B.A., Weenink, T. \& Ellis, T. 2012. Construction of synthetic regulatory networks in yeast. FEBS Letters 586(15): 2112-2121.

Busso, D., Peleg, Y., Heidebrecht, T., Romier, C., Jacobovitch, Y., Dantes, A., Salim, L., Troesch, E., Schuetz, A., Heinemann, U., Folkers, G.E., Geerlof, A., Wilmanns, M., Polewacz, A., Quedenau, C., Büssow, K., Adamson, R., Blagova, E., Walton, J., Cartwright, J.L., Bird, L.E., Owens, R.J., Berrow, N.S., Wilson, K.S., Sussman, J.L., Perrakis, A \& Celie, P.H. 2011. Expression of protein complexes using multiple Escherichia coli protein co-expression systems: A benchmarking study. Journal of Structural Biology 175(2): 159-170.

Chen, C. 2016. Superior cloning performance with SGI-DNA gibson assembly® kits. Biotechniques 60(3): 151-152.

Cohen, S.N., Chang, A.C.Y., Boyer, H.W. \& Helling, R.B. 1973. Construction of biologically functional bacterial plasmids in vitro. Proceedings of the National Academy of Sciences 70(11): 3240-3244.

Festa, F., Steel, J., Bian, X. \& Labaer, J. 2013. High-throughput cloning and expression library creation for functional proteomics. Proteomics 13(9): 1381-1399.

Galanie, S., Thodey, K., Trenchard, I.J., Filsinger Interrante, M. \& Smolke, C.D. 2015. Complete biosynthesis of opioids in yeast. Science 349(6252): 1095-1100.

Hartley, J.L., Temple, G.F. \& Brasch, M.A. 2000. DNA cloning using in vitro site-specific recombination. Genome Research 10(11): 1788-1795.

Hawkins, K.M. \& Smolke, C.D. 2008. Production of benzylisoquinoline alkaloids in Saccharomyces cerevisiae. Nature Chemical Biology 4(9): 564-573.

Jiang, H., Wood, K.V. \& Morgan, J.A. 2005. Metabolic engineering of the phenylpropanoid pathway in Saccharomyces cerevisiae. Applied Environmental Microbiology 71(6): 2962-2969.

Koopman, F., Beekwilder, J., Crimi, B., van Houwelingen, A., Hall, R.D., Bosch, D., van Maris, A.J., Pronk, J.T. \& Daran, J.M. 2012. de novo production of the flavonoid naringenin in engineered Saccharomyces cerevisiae. Microbial Cell Factories 11(1): 155.

Leonard, E. \& Koffas, M.A.G. 2007. Engineering of artificial plant cytochrome P450 enzymes for synthesis of isoflavones by Escherichia coli. Applied Environmental Microbiology 73(22): 7246-7251.

Liu, L., Redden, H. \& Alper, H.S. 2013. Frontiers of yeast metabolic engineering: Diversifying beyond ethanol and Saccharomyces. Curr. Opin. Biotechnol. 24(6): 1023-1030.

Loke, K.K., Rahnamaie-Tajadod, R., Yeoh, C.C., Goh, H.H., Mohamed-Hussein, Z.A., Zainal, Z., Ismail, I. \& Mohd
Noor, N. 2017. Transcriptome analysis of Polygonum minus reveals candidate genes involved in important secondary metabolic pathways of phenylpropanoids and flavonoids. PeerJ 5: e2938.

Loke, K.K., Rahnamaie-Tajadod, R., Yeoh, C.C., Goh, H.H., Mohamed-Hussein, Z.A., Mohd Noor, N., Zainal, Z. \& Ismail, I. 2016. RNA-seq analysis for secondary metabolite pathway gene discovery in Polygonum minus. Genomics Data 7: 12-13.

Luo, Y., Enghiad, B. \& Zhao, H. 2016. New tools for reconstruction and heterologous expression of natural product biosynthetic gene clusters. Natural Products Reports 33(2): 174-182.

Ramzi, A.B., Hyeon, J.E. \& Han, S.O. 2015. Improved catalytic activities of a dye-decolorizing peroxidase (DyP) by overexpression of ALA and heme biosynthesis genes in Escherichia coli. Process Biochemistry 50(8): 1272-1276.

Sambrook, J., Fritsch, E.F. \& Maniatis, T. 1989. Molecular Cloning: A Laboratory Manual.2nd ed. Cold Spring: Harbor Laboratory Press.

Sherman, F. 1991. Getting started with yeast. Methods in Enzymology 194: 3-21.

Siddiqui, M.S., Thodey, K., Trenchard, I. \& Smolke, C.D. 2012. Advancing secondary metabolite biosynthesis in yeast with yeast synthetic biology tools. FEMS Yeast Research 12(2): 144-170.

Smanski, M.J., Zhou, H., Claesen, J., Shen, B., Fischbach, M.A. \& Voigt, C.A. 2016. Synthetic biology to access and expand nature's chemical diversity. Nature Reviews Microbiology 14(3): 135-149.

Stephanopoulos, G. 2012. Synthetic biology and metabolic engineering. ACS Synthetic Biology 1(11): 514-525.

Trantas, E., Panopoulos, N. \& Ververidis, F. 2009. Metabolic engineering of the complete pathway leading to heterologous biosynthesis of various flavonoids and stilbenoids in Saccharomyces cerevisiae. Metabolic Engineering 11(6): 355-366.

Vickers, C.E., Bydder, S.F., Zhou, Y. \& Nielsen, L.K. 2013. Dual gene expression cassette vectors with antibiotic selection markers for engineering in Saccharomyces cerevisiae. Microbial Cell Factories 12(1): 96.

Wang, T., Ma, X., Zhu, H., Li, A., Du, G. \& Chen, J. 2012. Available methods for assembling expression cassettes for synthetic biology. Applied Microbiology and Biotechnology 93(5): 1853-1863.

Yan, Y., Kohli, A. \& Koffas, M.A.G. 2005. Biosynthesis of natural flavanones in Saccharomyces cerevisiae. Applied Environmental Microbiology 71(9): 5610-5613.

Institute of Systems Biology (INBIOSIS)

Universiti Kebangsaan Malaysia

43600 UKM Bangi, Selangor Darul Ehsan

Malaysia

*Corresponding author; email: bazliramzi@ukm.edu.my

Received: 30 May 2018

Accepted: 18 September 2018 